\title{
Growth, Yield and Water Productivity of Scented Rice (Oryza sativa L.) as Influenced by Planting Techniques and Integrated Nutrient Management Practice
}

\author{
Vivek Kumar ${ }^{1}$, R.K. Naresh ${ }^{2 *}$, V.K. Tomar ${ }^{3}$, Rakesh Kumar ${ }^{1}$, Vivek ${ }^{2}$,

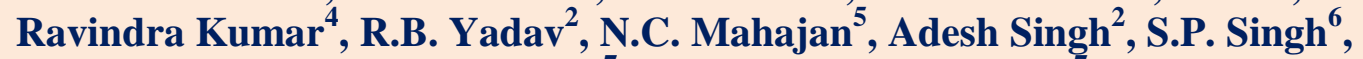 \\ Subhash Chandra ${ }^{7}$ and Omkar Singh Yadav ${ }^{7}$
}

${ }^{I}$ Krishak Bharati Cooperative Ltd (KRIBHCO), Khandri Chourha, Agra, (U.P.), India

${ }^{2}$ Department of Agronomy, ${ }^{4}$ Department of Cell Biology; ${ }^{6}$ Department of Soil Science, India

Sardar Vallabhbhai Patel University of Agriculture and Technology, Meerut, (UP)

${ }^{3}$ Krishak Bharati Cooperative Ltd (KRIBHCO), Vibhuti Khand, Gomti Nagar, Lucknow, (U.P.), India

${ }^{5}$ Department of Agronomy, Institute of Agricultural Sciences, Banaras Hindu University, Varanasi(U.P), India

${ }^{7}$ K. V. K. Hazratpur Firozabad, Chandrashekhar Azad University of Agriculture \& Technology, Kanpur-(U.P.), India

*Corresponding author

\begin{tabular}{|l|}
\hline Ke y w o r d s \\
$\begin{array}{l}\text { Planting techniques, } \\
\text { integrated nutrient } \\
\text { management, crop- } \\
\text { water productivity }\end{array}$ \\
\hline Article Info \\
\hline $\begin{array}{l}\text { Accepted: } \\
\text { 12 May 2019 } \\
\text { Available Online: } \\
\text { 10 June } 2019\end{array}$ \\
\hline
\end{tabular}

\section{A B S T R A C T}

Exploiting the production potential of high yielding rice varieties through agronomic management is one of the alternatives to feed the ever growing population. For this, fertilizers from different sources and modern planting techniques have contributed substantially to the spectacular increase in rice yield and to improve soil properties. In order to study the effect of planting techniques and integrated nutrient management in rice. A field experiments was conducted at Crop Research Centre of Sardar Vallabhbhai Patel University of Agriculture \& Technology, Meerut (Utter Pradesh) during Kharif 2017. The experiment was laid out in split plot design with three replications. The treatment consisted of three planting techniques $\left(\mathrm{P}_{1}\right.$ - conventional puddled transplanting (CT-TPR), $\mathrm{P}_{2^{-}}$wide raised beds transplanted rice (WB-TPR) and $\mathrm{P}_{3}$ - reduced till transplanted rice (RT-TPR) and ten integrated nutrient management ( $F_{1}$ - control, (no fertilizer), $\mathrm{F}_{2}-\mathrm{RDF}$ (150-60-40 kg NPK/ha), $\mathrm{F}_{3}-75 \% \mathrm{RDF}+\mathrm{FYM} 5 \mathrm{t} / \mathrm{ha}, \mathrm{F}_{4}-75 \% \mathrm{RDF}+$ FYM 5 t/ha + Zn, F $5^{-} 75 \%$ RDF + FYM 5 t/ha + BF, F $6^{-}$75\% RDF + FYM 5 t/ha +BF + Zn, F $7^{-}$100\% $\mathrm{RDF}+\mathrm{FYM} 5 \mathrm{t} / \mathrm{ha}, \mathrm{F}_{8^{-}} 100 \% \mathrm{RDF}+\mathrm{FYM} 5 \mathrm{t} / \mathrm{ha}+\mathrm{Zn}, \mathrm{F}_{9^{-}}-100 \% \mathrm{RDF}+\mathrm{FYM} 5 \mathrm{t} / \mathrm{ha}+\mathrm{BF}$ and $\mathrm{F}_{10^{-}} 100 \%$ $\mathrm{RDF}$ FYM $5 \mathrm{t} / \mathrm{ha}+\mathrm{BF}+\mathrm{Zn}$ in this way there were 30 treatment combinations. The values of growth contributing characters viz. plant height $(\mathrm{cm})$, number of tillers $\mathrm{m}^{-2}$, dry matter accumulation $\left(\mathrm{g} \mathrm{m}^{-2}\right)$, and yield attributes like number of panicles $\mathrm{m}^{-2}$, length of panicle $(\mathrm{cm})$, number of panicle ${ }^{-1}$, grain weight panicle $^{-1}$, test weight $(\mathrm{g})$, grain and straw yield $\left(\mathrm{q} \mathrm{ha}^{-1}\right)$ of rice were increasing significantly with conventional puddled transplanted method $\left(\mathrm{P}_{1}\right)$ followed by wide raised beds transplanted method $\left(\mathrm{P}_{2}\right)$ and significantly superior over rest of the treatments. In case of integrated nutrient management the growth characters like plant height $(\mathrm{cm})$, number of tillers $\mathrm{m}^{-2}$, dry matter accumulation $(\mathrm{g})$, yield attributes' number of panicle $\mathrm{m}^{-2}$ length of panicle, grain weight panicle ${ }^{-1}$, test weight $(\mathrm{g})$, grain and straw yield ( $\mathrm{q}$ ha $^{-}$ $\left.{ }^{1}\right)$ of rice were maximum under $\mathrm{F}_{10}(100 \% \mathrm{RDF}+5 \mathrm{t} / \mathrm{ha} \mathrm{FYM}+\mathrm{BF}+\mathrm{Zn})$ which was at par with $\mathrm{F}_{9}(100 \%$ $\mathrm{RDF}+5 \mathrm{t} / \mathrm{ha} \mathrm{FYM}+\mathrm{BF}$ ) during course of investigation. The maximum gross return and net return were noted under $\mathrm{P}_{2}$ (wide raised beds transplanted rice) with $\mathrm{F}_{10}(100 \% \mathrm{RDF}+5 \mathrm{t} / \mathrm{ha} \mathrm{FYM}+\mathrm{BF}+\mathrm{Zn})\left[\mathrm{P}_{2} \mathrm{~F}_{10}\right]$ application. The highest benefit cost ratio were recorded with WB-TPR SRI method with $(100 \%$ $\mathrm{RDF}+5 \mathrm{t} / \mathrm{ha} \mathrm{FYM}+\mathrm{BF}+\mathrm{Zn})$ treatment $\left(\mathrm{P}_{2} \mathrm{~F}_{10}\right)$ followed by WB-TPR with $(100 \% \mathrm{RDF}+5 \mathrm{t} / \mathrm{ha} \mathrm{FYM}+\mathrm{BF})$ $\left(\mathrm{P}_{2} \mathrm{~F}_{9}\right)$ they proved more remunerative then other treatment combinations. CT-TPR used higher amount of water than WB-TPR, with water saving of $14.5 \%$ in WB-TPR. Significantly higher water productivity was recorded in WB-TPR as compared to CT-TPR. 


\section{Introduction}

Rice is one of the most important cereal crops of kharif season. Rice is cultivated worldwide over an area of about 161.5 million ha ${ }^{-1}$ with an annual production of about 751.9 million tonnes (FAO, 2017). In India rice is cultivated over an area of about 43.38 million hectares with an annual production of about 104.32 million tonnes and the productivity of 2.40 tonnes $\mathrm{ha}^{-1}$ (Anonymous, 2016). In India, it accounts for more than $40 \%$ of food grain production, providing direct employment to $70 \%$ people in rural areas. Utter Pradesh is an important rice growing state in the country. The area and production of rice in this state is about 15.98 million hectare and 14.64 million tonnes respectively with an average production of 2.45 tonnes (FAS 2014-15). Production of rice rank second among the food grain and half of the world population receiving the highest $(26.2 \%)$ calories intake from it in the developing countries of their dietary protein (FAO, 2009). Rice is an excellent source of carbohydrate and to a certain extent it provides protein to regular human diet. So it is used as staple food crop by about half of the world population and eaten as cooked rice and also used for various preparations inhabiting in the humid tropics and subtropics. Further, rice has commercial and industrial importance also beside grains. Rice straw and rice hulls are used as fodder, mulching, packing and as insulation material etc. Hence, the importance of rice crop in the country can't be negated.

The scarcity of water for agriculture production is becoming a major problem in many countries, particularly in word's leading rice-producing countries like China and India. Rice cultivation in India is predominantly practiced under transplanting method that involves raising, uprooting and transplanting of seedlings. This technique requires continuous ponding of water. To avoid these difficulties several other techniques of rice cultivation have been developed so far. Among those wide FIRB (furrow irrigated raised beds), reduced till unpuddled transplanted rice technique are gaining acceptance by the growers day by day. Raised beds are formed by moving soil from the furrows to the area of the bed, thus raising its surface level. The furrows serve as irrigation channels, drains and traffic lanes. Generally, two to six rows is planted on the top of each bed for rice crop (Naresh et al., 2011). Raised bed dimensions and configurations vary with soil type and available machinery. The ability of the soil to 'sub' (i.e. allow the lateral movement of irrigation water into the centre of the bed) is a key determinant of bed dimensions. For sandy loam soils that sub easily, growers use bed widths at $1.37 \mathrm{~m}$ centers for all crop types like rice, wheat. Soils do not sub as well; narrower beds at $0.67 \mathrm{~m}$ centers are frequently used. Bed height may also vary with soil conditions and field slope. Higher beds are frequently used on soils that sub well and have flatter grades and longer run lengths, while beds of a lower height are used on steeper graded fields. The flat top of the bed varies from 0.37 to $1.07 \mathrm{~m}$ in width. Furrow irrigation used with raised beds requires growers to adopt a whole-farm planning approach to deal with drainage water and the integration of on farm drains and drainage water recycling systems, to increase both water use efficiency and drainage water quality control (Beecher et al., 2005).

Rice plant requires an adequate supply of nutrients from various sources for optimal growth. These nutrients are supplied by indigenous sources such as soil minerals, soil organic matter, rice straw, manure, and water but the amount supplied is usually insufficient to achieve high and sustainable yields. Fertilizers need to be applied to overcome the deficit between crop requirement and nutrient supply from the above-mentioned sources. 
The crop requirement of nutrients depends on variety and season. However, the full potential of improved nutrient management can only be reached with good crop management. An effective agronomic management is therefore necessary to exploit the yield potential of rice. Integrated nutrient management (INM) involving organic and inorganic sources of nutrient are very important in rice production. Many of our problems on declining productivity can be traced to improper and inefficient use of nutrients. Improper nutrient management has resulted in the nutrient imbalances in the soil with nutrients in excess while other nutrients depleted. Through this, farmers can increase agricultural productivity and safeguard the environment as they efficiently use fertilizer. Diverse studies across different agroecosystems have shown importance of organic nutrient sources in improving crop yield and improving soil quality. Tripathi et al., (2013) reported that response of rice to nutrient supply by organic and inorganic fertilizer is universal but may vary with locations, soil and fertilizer types. Hence, the objective of this paper is to recommend the best proportion of organic and inorganic source of fertilizers in integrated nutrient management system and planting technique save the resources for sustainable rice production and soil improvements.

\section{Materials and Methods}

The experiment was laid out during Kharif 2017 at Crop Research Centre of Sardar Vallabhbhai Patel University of Agriculture \& Technology, Meerut $\left(29^{0} 04^{\prime}, \mathrm{N}\right.$ latitude and $77^{\circ} 42^{\prime}$ ' $\mathrm{E}$ longitude a height of $237 \mathrm{~m}$ above mean sea level), Uttar Pradesh Province, India. The region has a semi-arid sub-tropical climate with an average annual temperature of $16.8{ }^{0} \mathrm{C}$. The highest mean monthly temperature $\left(38.9{ }^{\circ} \mathrm{C}\right)$ is recorded in May, and the lowest mean monthly temperature $\left(4.5^{0} \mathrm{C}\right)$ is recorded in January. The average annual rainfall is about 665 to $726 \mathrm{~mm}$ (constituting $44 \%$ of pan evaporation) of which about $80 \%$ is received during the monsoon period. The predominant soil at the experimental site is classified as Typic Ustochrept. Soil samples for $0-15 \mathrm{~cm}$ depth at the site were collected and tested prior to applying treatments and the basic properties were low available nitrogen, low organic carbon, available phosphorus, available potassium medium and alkali in reaction.

The experimental was laid out in Split plot design (SPD) where 30 treatments were replicated three times. In all, there were 30 treatments included in the experiment in main plot and sub plot. The detail of treatments with their symbols three planting techniques [ $\left(\mathrm{P}_{1^{-}}\right.$conventional puddled transplanting (CTTPR), $\mathrm{P}_{2^{-}}$wide raised beds transplanted rice (WB-TPR) and $\mathrm{P}_{3^{-}}$- reduced till transplanted rice (RT-TPR)] and ten integrated management practices $\left[\left(\mathrm{F}_{1}-\right.\right.$ control, (no fertilizer), $F_{2}-$ RDF (150-60-40 kg NPK/ha), $\mathrm{F}_{3}-75 \% \mathrm{RDF}+\mathrm{FYM} 5 \mathrm{t} / \mathrm{ha}, \mathrm{F}_{4}-75 \% \mathrm{RDF}+$ FYM 5 t/ha + Zn, F $_{5}-75 \%$ RDF + FYM 5 t/ha $+\mathrm{BF}, \mathrm{F}_{6}-75 \% \mathrm{RDF}+\mathrm{FYM} 5 \mathrm{t} / \mathrm{ha}+\mathrm{BF}+\mathrm{Zn}$, $\mathrm{F}_{7}-100 \% \mathrm{RDF}+\mathrm{FYM} 5 \mathrm{t} / \mathrm{ha}, \mathrm{F}_{8}-100 \% \mathrm{RDF}$ + FYM 5 t/ha + Zn, F $9^{-}$100\% RDF + FYM 5 $\mathrm{t} / \mathrm{ha}+\mathrm{BF}$ and $\mathrm{F}_{10^{-}} 100 \% \mathrm{RDF}+\mathrm{FYM} 5 \mathrm{t} / \mathrm{ha}$ $+\mathrm{BF}+\mathrm{Zn}]$. A common procedure was followed in raising seedlings in the seedbed. The seedbed was prepared by puddling with repeated ploughing followed by laddering. Weeds were removed and irrigation was gently provided to the bed as and when necessary.

In conventional-till puddle transplanted rice (CT-TPR) land was ploughed, puddle and leveled and 21-day-old seedlings were manually transplanted at a hill spacing of 20x10 cm with two seedling hill $^{-1}$ and for reduced till (un-puddle) transplanted rice (RT- 
TPR) 1-2- dry tillage followed by planking/leveling and pounding water but without puddling; 21-dayold seedlings were transplanted in rows. Transplanted rice on raised beds (WB-TPR) a bed former-cumzero-till drill is used to form $107 \mathrm{~cm}$ wide raised bed and $30 \mathrm{~cm}$ wide furrows in well prepared pulverized soil; 21-day old seedlings were transplanted in six rows at $20-\mathrm{cm}$ spacing on the top of the raised beds. Plant-toplant spacing was $10 \mathrm{~cm}$ to maintain the population equal to that of the conventional transplanted method. The specific quantity of each fertilizer was calculated on the basis of gross plot size and as per treatment taken per plot. The optimum dose of manure and fertilizers was recorded for rice. The half quantity of nitrogen and full quantity of phosphorus and potassium were broadcasted in the field during final field preparation after the transplanting and sowing the fertilizer thoroughly in the field. The rest half dose of nitrogen was top dressed in two splits after first irrigation and second 45 DAT. Plant nutrients in organic plots were applied through FYM. For absolute control, nothing was applied for entire crop season. The field observations on plant growth and development parameters, growth induces, and grain and biological yield were assess using standard procedures (Rana et al., 2014).

The crop was harvested manually by serrated edged sickles at physiological maturity when panicle had about $85 \%$ ripened spikelet and upper portion of spikelet look straw coloured. At the time of harvesting the grains were subjected to hard enough, having less than 16 per cent moisture in the grains. First of all, the border area was harvested. The harvesting of net plot area was done separately and the harvested material from each net plot was carefully bundled and tagged after drying for three days in the field and then brought to the threshing floor. The bundle of harvested produce of each net plot was weighed after sun drying for recording biological yield. Threshing of each bundle of individual plot was done manually by wooden sticks. The grain yield of individual plot after winnowing was weighed. The quantity of straw per plot was calculated by subtracting the weight of grains from biological produce. Yield of both grain and straw was expressed in $\mathrm{q} \mathrm{ha}^{-1}$.

\section{Results and Discussion}

\section{Growth characters}

\section{Plant height}

Plant height was significantly influenced by various planting techniques at all the stages of crop growth (Fig. 1a). Maximum plant height was recorded with the wide raised beds transplanted rice $\left(\mathrm{P}_{2}\right)$ [WB-TPR] which was statistically at par with the conventional puddled transplanting method (CT-TPR) and significantly superior to rest of the treatments at all the stages of crop growth.

Wider spacing particularly under in WB-TPR method recorded significantly taller plant than the closer spacing, due to the fact that under wider spacing, the plant get sufficient space above the ground (shoot) and below the ground (root) to grow as well as the increased light transmission in the canopy, leading to greater plant height. At harvest, the tallest plants were recorded in WB-TPR. It might be due to more space, sunlight and nutrients available to wider spaced plants of WB-TPR than close spaced plants which facilitated the plants to attain more height. Shrirame et al., (2000) reported that the number of functional leaves and leaf area were higher under wider spacing, which increased the photosynthetic rate leading to taller plant.

Plant height influenced by integrated nutrient management was significant at 30 days of DAT of the crop (Fig. 1a). Significantly 
higher plant height was recorded where application of $100 \% \mathrm{RDF}+\mathrm{FYM} 5 \mathrm{t} / \mathrm{ha}+\mathrm{BF}$ $+\mathrm{Zn}\left(\mathrm{F}_{10}\right)$ through inorganic and organic fertilizer was given and it remained at par with $100 \%$ RDF + FYM 5t/ha +BF $\left(\mathrm{F}_{9}\right)$ plots. Plant height increased mainly due to adequate nutrient supply to the plant which resulted into rapid growth by good establishment of root and various metabolic processes and ultimately performed better mobilization of synthesized carbohydrates in to amino acid and protein which stimulated the rapid cell division and cell elongation. Finally, it resulted in to growth of plant faster as compare to other treatments tested during in course of investigation. The lowest plant height was recorded under control (no fertilizer) $\left(F_{1}\right)$ at all growth stags. It might be due to poor availability of nutrient which caused poor growth and poor nutrient mobilization. Similar findings were recorded by Bhuyan et al., (2012) and Kumhar et al., (2016).

\section{Number of tillers $\left(\mathrm{m}^{-2}\right)$ and Dry matter accumulation $\left(\mathrm{g} \mathrm{m}^{-2}\right)$}

The number of tillers was significantly affected by various planting techniques at different stages of crop growth (Fig. 1b). The highest numbers of tillers $\mathrm{m}^{-2}$ were recorded in CT-TPR $\left(\mathrm{P}_{1}\right)$ which was at par with wide raised transplanted rice WB-TPR $\left(\mathrm{P}_{2}\right)$ at 30 days of transplanting.

Significantly higher number of tillers was counted under CT-TPR technique as compared to rest of the treatments at 60,90and harvest stages except WB-TPR plots. The higher number of tillers hill ${ }^{-1}$ might be due to better water management (Uphoff, 2003). Alternate wetting and drying maintaining a thin film of water that might open the soil for both oxygen and nitrogen and promoted the root growth during initial growth stages which ultimately increased tiller density
(Thakur et al., 2010). Dry matter accumulation indicates towards the photosynthetic left behind after respiration. So it is the best indicator of growth of a crop. Among different tillage crop establishment methods CT-TPR [conventional till with puddled transplanted rice, $\left(\mathrm{P}_{1}\right)$ ] accumulated more dry matter which was statistically at par with rice transplanted under wide raised beds $\mathrm{W}$ Bed-TPR $\left(\mathrm{P}_{2}\right)$. However, the differences among $\mathrm{P}_{2}$ and $\mathrm{P}_{3}$ treatments were nonsignificant (Fig. 1c).

Integrated nutrient management affected significantly higher number of tiller $\mathrm{m}^{-2}$ (Fig 1b). The significantly higher number of tiller $\mathrm{m}^{-2}$ was recorded with $100 \% \mathrm{RDF}+\mathrm{FYM}$ $5 \mathrm{t} / \mathrm{ha}+\mathrm{BF}+\mathrm{Zn}\left(\mathrm{F}_{10}\right)$ through inorganic and organic fertilizer which was at par with $100 \%$ $\mathrm{RDF}+\mathrm{FYM} 5 \mathrm{t} / \mathrm{ha}+\mathrm{BF}\left(\mathrm{F}_{9}\right)$ as compared to rest of the treatment.

It might be attributed to adequate nutrient availability which provided favourable condition for better synthesis of growth favouring constituents in plant system. The lower number of tillers was recorded under control (no fertilizer) $\left(\mathrm{F}_{1}\right)$ at all growth stages mainly due to inadequate nutrient supply system. The results of the present investigation are in close conformity with the findings of Ramesh et al., (2009), and Yadav et al., (2013).

Integrated nutrient management affected significantly the dry matter accumulation $\left(\mathrm{gm}^{-2}\right)$ at all growth stages 30, 60, 90 and harvest stages, as well. Higher dry matter accumulation was recorded under $100 \%$ $\mathrm{RDF}+\mathrm{FYM} 5 \mathrm{t} / \mathrm{ha}+\mathrm{BF}+\mathrm{Zn}\left(\mathrm{F}_{10}\right)$ through inorganic and organic fertilizer which was at par with $100 \% \mathrm{RDF}+\mathrm{FYM} 5 \mathrm{t} / \mathrm{ha}+\mathrm{BF}\left(\mathrm{F}_{9}\right)$ as compared to rest of the treatment. In the present study the fact was further elucidated as more dry matter accumulation were recorded in all those treatment where nitrogen 
supply was more. This low growth in these treatments may be due to low availability of plant nutrient which are necessary for the normal growth. Nitrogen being the basic constituent of chlorophyll, protein and cellulose required for the process of photosynthesis and tissue build up for proper growth.

Lower dry matter accumulation was recorded under treatment $F_{1}$ control (no fertilizer) at all growth stages mainly due to in adequate nutrient supply resulting in reduction in plant height, number of leaves, number of shoots/hill and nutrient absorption from the soil. Finally it led to decline in photosynthesis activity which ultimately recorded lowest dry matter accumulation (Kumar et al., 2013).

\section{Yield attributing characters}

The data pertaining to yield attributes as influenced by nutrient management practices is depicted in Figure 2a. All the yield attributes viz., number of effective tillers $\mathrm{m}^{-2}$, length of panicle, number of grain panicle ${ }^{-1}$ and test weight are the resultant of vegetative development of the crop which determine yield were influenced by various organic manures, fertilizers and inoculants.

The maximum effective tillers $\mathrm{m}^{-2}$ was recorded with $100 \% \mathrm{RDF}+5 \mathrm{t} / \mathrm{ha} \mathrm{FYM}+25$ $\mathrm{kg}$ Zinc ha ${ }^{-1}+\mathrm{BF}\left(\mathrm{F}_{10}\right)$ treatment which was at par to $100 \% \mathrm{RDF}+5 \mathrm{t} / \mathrm{ha} \mathrm{FYM}+\mathrm{BF}\left(\mathrm{F}_{9}\right)$ and $75 \% \mathrm{RDF}+5 \mathrm{t} / \mathrm{ha} \mathrm{FYM}+25 \mathrm{~kg} \mathrm{Zinc} \mathrm{ha}^{-1}+\mathrm{BF}$ $\left(\mathrm{F}_{7}\right)$ treatments which was significantly superior over other treatments. The maximum length of panicle was obtained with integrated $100 \% \mathrm{RDF}+5 \mathrm{t} / \mathrm{ha} \mathrm{FYM}+25 \mathrm{~kg} \mathrm{Zinc} \mathrm{ha}^{-1}+$ $\mathrm{BF}\left(\mathrm{F}_{10}\right)$ treatment which was at par to $100 \%$ $\mathrm{RDF}+5 \mathrm{t} / \mathrm{ha} \mathrm{FYM}+\mathrm{BF}\left(\mathrm{F}_{9}\right)$ treatment which was significantly superior to rest of the treatments. The maximum number of grain panicle $^{-1}$ was observed and obtained with integrated $100 \% \mathrm{RDF}+5 \mathrm{t} / \mathrm{ha} \mathrm{FYM}+25 \mathrm{~kg}$ Zinc $\mathrm{ha}^{-1}+\mathrm{BF}$ treatment which was at par to
$100 \% \mathrm{RDF}+5 \mathrm{t} / \mathrm{ha} \mathrm{FYM}+\mathrm{BF}$ treatment which was significantly superior to rest of the treatments. The effect of various treatments did not influence on test weight significantly.

The increase in yield attributes was mainly due to increase in photosynthesis activity of leaves, translocation of photosynthesis from source to sink and nutrients uptake under higher nutrients availability.

The minimum values of the entire yield attributes were observed in the treatment received no fertilizer "control" because plants did not get sufficient amount of nutrients which resulted in poor yield attributes. This was also evidenced by studies of Singh and Singh (2008), Kumar et al., (2010) and Sridevi (2011).

Number of spikelet's panicle ${ }^{-1}$ is one of the most yield attribute. Similarly the grain is fertilized; fully ripened ovule of spikelet in a panicle that ultimately contributes to grain yield. This excludes sterile spikelet's panicle $^{-1}$. The weight of individual grain calculated from 1000 grain weight (test weight) is an important yield attribute which provides information regarding the efficiency with grain filling process took place.

Thousand grain weight (1000 grain weight), as it is called the test weight of the desired output, is referred to be considered as one of the most significant agronomic parameters ever trusted that contributes in having a reconnaissance over the possible production of a lot (grain yield).

Figure $2 \mathrm{a}$ advocated that the maximum yield attributes were recorded significantly superior in $\mathrm{P}_{2}$ treatment as compared to all other treatments except $\mathrm{P}_{1}$. Treatments $\mathrm{P}_{1}$ and $\mathrm{P}_{3}$ were at par with each other; however, $\mathrm{P}_{3}$ treatment which recorded minimum yield attributes. 
Fig.1 Effect of different planting techniques and fertility level on (a) plant height (cm), (b) number of tillers $\left(\mathrm{m}^{-2}\right)$ and $(\mathrm{c})$ dry matter accumulation $\left(\mathrm{g} \mathrm{m}^{-2}\right)$ of rice

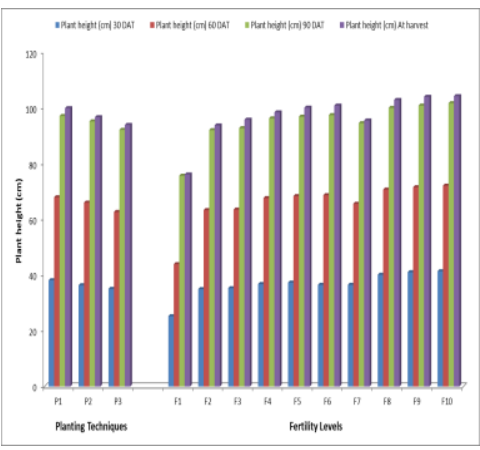

(a)

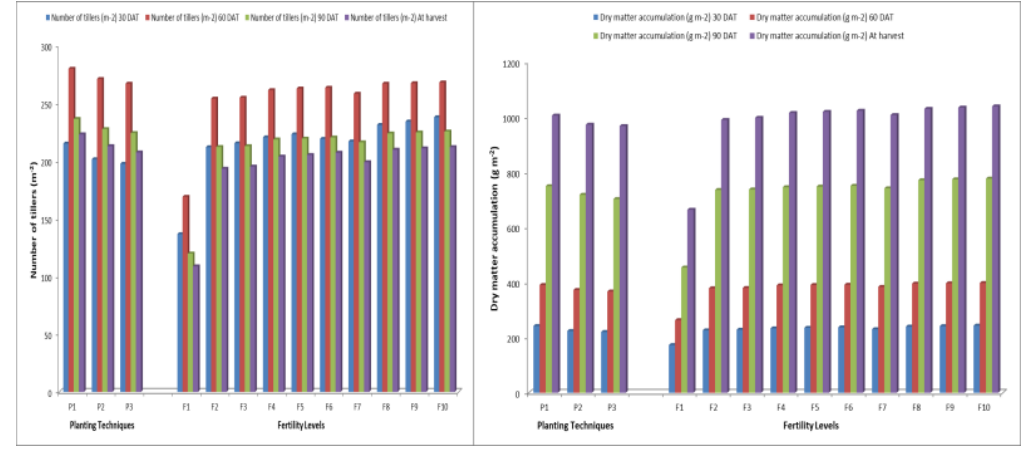

(b) (c)

Fig.2 Effect of different planting techniques and fertility levels on (a) yield contributing characteristics and (b) grain yield $\left(\mathrm{q} \mathrm{ha}^{-1}\right)$, Straw yield $\left(\mathrm{q} \mathrm{ha}{ }^{-1}\right)$, biological yield $\left(\mathrm{q} \mathrm{ha}^{-1}\right)$ and harvest index $(\%)$ of rice

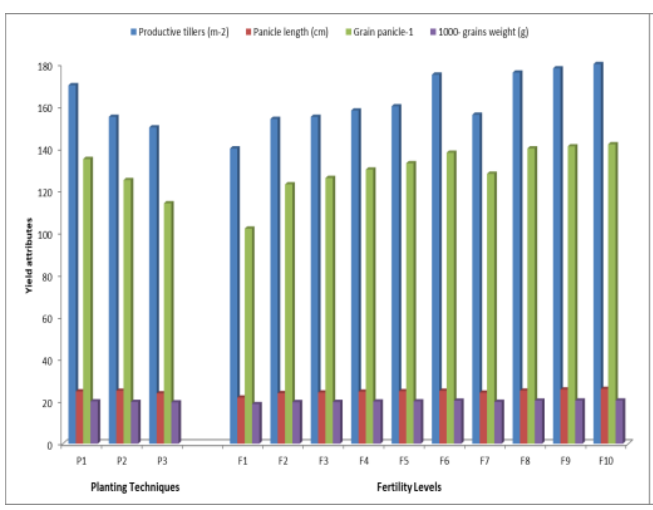

(a)

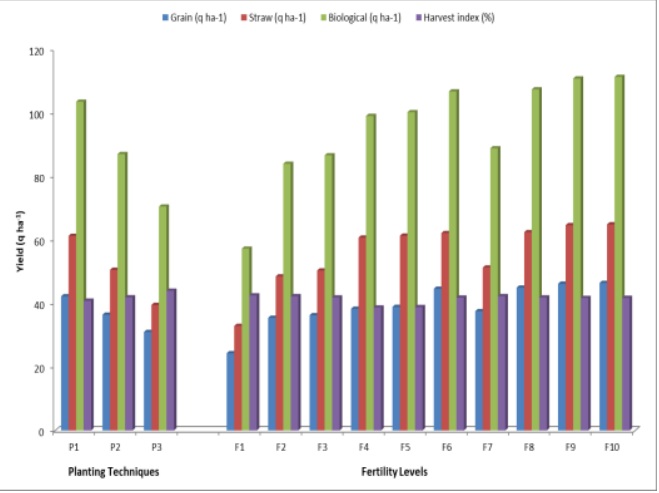

(b)

Fig.3 Profitability of rice as affected by various different planting techniques and fertility level

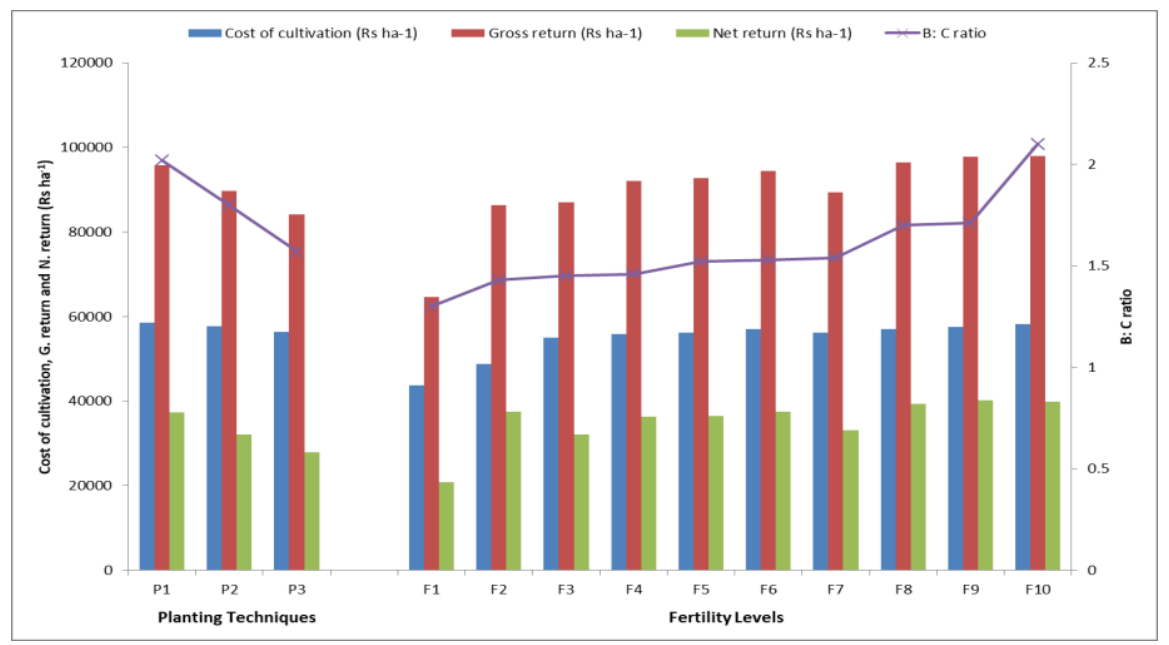


Table.1 Physico-chemical properties of the experimental field Soil

\begin{tabular}{|c|c|c|}
\hline Soil parameters/ characteristic & $\begin{array}{l}\text { Value } \\
\text { obtained }\end{array}$ & Methods adopted \\
\hline \multicolumn{3}{|l|}{ A. Physical properties } \\
\hline Sand $(\%)$ & 53.16 & \multirow{3}{*}{ Hydrometer method (Piper, 1966) } \\
\hline Clay (\%) & 17.64 & \\
\hline Silt (\%) & 27.93 & \\
\hline Textural class & Sandy loam & Triangular basis \\
\hline \multicolumn{3}{|l|}{ B. Physical constants } \\
\hline Field capacity (\%) & 27.03 & \multirow[t]{2}{*}{ Field method (Dastane, 1967) } \\
\hline Permanent wilting point (\%) & 11.32 & \\
\hline Bulk density $\left(\mathrm{Mg} / \mathrm{m}^{3}\right)$ & 1.51 & Core sampler method (Piper, 1966) \\
\hline \multicolumn{3}{|l|}{ C. Chemicalcomposition } \\
\hline Available $\mathrm{N}\left(\mathrm{Kg} \mathrm{ha}^{-1}\right)$ & 244.5 & $\begin{array}{l}\text { Alkaline potassium permanganate method } \\
\text { (Subbiah and Asija, 1956) }\end{array}$ \\
\hline Available $\mathrm{P}\left(\mathrm{Kg} \mathrm{ha}^{-1}\right)$ & 12.3 & Olsen's method (Jackson, 1973) \\
\hline Available $\mathrm{K}\left(\mathrm{Kg} \mathrm{ha}^{-1}\right)$ & 201.8 & $\begin{array}{l}\text { 1N NH} H_{4} \mathrm{OAC} \text { extraction method (Jackson, } \\
1973 \text { ) }\end{array}$ \\
\hline Organic Carbon (\%) & 0.51 & $\begin{array}{l}\text { Walkley and Black wet oxidation } \\
\text { (Jackson, 1973) }\end{array}$ \\
\hline $\mathrm{P}^{\mathrm{H}}$ (soil: water $1: 2.5$ ) & 7.6 & $\begin{array}{l}\text { Electrode } \mathrm{P}^{\mathrm{H}} \text { meter Suspension method } \\
\text { (Page et al., 1982) }\end{array}$ \\
\hline Electrical conductivity $\left(\mathrm{dSm}^{-1}\right)$ & 0.22 & $\begin{array}{l}\text { Conductivity meter Suspension method } \\
\text { (Page et al., 1982) }\end{array}$ \\
\hline
\end{tabular}

Table.2 Soil profile water extraction patterns under different treatments

\begin{tabular}{|l|l|l|l|l|l|}
\hline \multirow{2}{*}{ Treatments } & \multicolumn{3}{|l|}{ Total Soil Water Extraction $(\mathbf{m m})$} & \multicolumn{2}{|c|}{$\begin{array}{c}\text { Total moisture } \\
\text { depletion }(\mathbf{m m})\end{array}$} \\
\cline { 1 - 5 } & Depth of soil $(\mathbf{c m})$ & & \\
\cline { 2 - 5 } & $\mathbf{0 - 1 5}$ & $\mathbf{1 5 - 3 0}$ & $\mathbf{3 0 - 6 0}$ & $\mathbf{6 0 - 9 0}$ & \\
\hline $\mathbf{P}_{\mathbf{1}}$ CT-TPR & 358 & 298 & 157 & 77 & 890 \\
\hline $\mathbf{P}_{\mathbf{2}}$ WB-TPR & 312 & 225 & 196 & 119 & 852 \\
\hline $\mathbf{P}_{\mathbf{3}}$ RT-TPR & 329 & 248 & 171 & 92 & 840 \\
\hline Mean & $\mathbf{3 3 3}$ & $\mathbf{2 5 7}$ & $\mathbf{1 7 4 . 7}$ & $\mathbf{9 6}$ & $\mathbf{8 6 0 . 7}$ \\
\hline
\end{tabular}

\section{Yield parameters}

Yield is the resultant of coordinated interplay of growth characters and yield attributes. Grain and straw yield were influenced significantly by applying various organic manures, fertilizers and inoculants are depicted in Figure 2b.

The maximum grain yield, straw yield and higher harvest index was recorded in treatment $\mathrm{F}_{10}$ received $100 \%$ recommended NPK through fertilizers and 5t/ha FYM and $20 \mathrm{~kg}$ zinc/ha as basal and bio-fertilizer which was statistically at par to the treatment $F_{9}$ and was significantly superior over rest of the treatments. This might be due to adequate nutrient availability, which contributed to better growth parameters and yield attributes. Productivity of crop collectively determined 
by vigour of the vegetative growth and yield attributes which resulted in higher grain and straw yield. The increase in yield was further attributed to better translocation of photosynthetic from source to sink due to higher uptake of NPK which are responsible for quick and easy translocation of photosynthetic. The better vegetative growth coupled with high yield attributes resulted in higher grain and straw of rice Sengar et al., (2000). Lowest grain and yield were recorded under control plots (no fertilizer). This was due to poor growth and metabolic process and lesser number of grain/panicle. The results are in accordance with Reddy et al., (2002).

Figure $2 \mathrm{~b}$ revealed that the grain and straw yield increased significantly with the every successive increase in moisture supply by moisture retention and land configuration. Treatments $\mathrm{P}_{1}$ and $\mathrm{P}_{2}$ were at par with each other, however, they recorded significantly higher yield over rest of the treatments. Treatment $\mathrm{P}_{3}$ (reduced till rice transplanted) recorded minimum yield. Similar results have been reported by Dhaka et al., (2007), Ingle (2007) and Ali et al., (2012).

\section{Moisture extraction pattern}

The soil profile was divided in four layers $(0$ $15,15-30,30-60$ and $60-90 \mathrm{~cm}$ ) and the maximum amount of water was extracted (absorbed) from 0-15 cm layer followed by $15-30 \mathrm{~cm}, 30-60 \mathrm{~cm}$, and minimum from 60 $90 \mathrm{~cm}$ Table 2. The moisture extraction from the surface layer $(0-15 \mathrm{~cm})$ was increased slightly with conventional tillage and reduced tillage practices. Similarly, the moisture extraction was decreased slightly with increase in profile depth and furrow irrigated raised beds, respectively. Data also indicated that rice transplanted on wide raised beds and transplanted rice under reduced tillage plots consumed more moisture from the deeper profile layer than conventional tillage practice and vice-versa. The moisture extraction from the surface layer $(0-15 \mathrm{~cm})$ was increased slightly with increase in irrigation frequency during the year of study. Similarly, the moisture extraction was decreased slightly with increase in profile depth and irrigation frequency. Similar results have been reported by Naresh et al., (2015).

The effect of tillage practices under different water management on average profile soil moisture content in rice during experimentation is shown in Table 2. In general, the profile moisture content was highest at the time of transplanting $(>40 \%)$ and it was lowest at the time of crop maturity in all the treatments during the year of study. The increases in profile moisture content are visible from the peaks under planting techniques different were because of moisture conserved due to the application of irrigation frequency as per treatments. The moisture content of conventional tilled plots $\left(\mathrm{P}_{1}\right)$ under deeper depth was always lower than wide raised beds and reduced till plots $\left(\mathrm{P}_{2}\right)$ during the year of study except in the peaks where the moisture content in the profile was always same due to recharging of profile by application of irrigation/rainfall. The conventional till crop under all the planting techniques kept the average profile soil moisture content $1.5 \%$ lower than wide raised beds plots throughout the crop season except after recharging the soil profile either by application of irrigation or by rainfall.

\section{Economics}

The data indicates the highest cost of cultivation (Rs. 58530) was observed in the treatment $\left(\mathrm{P}_{1}\right)$ conventional puddled transplanted rice followed by $\left(\mathrm{P}_{2}\right)$ transplanted rice on wide raised beds. The lowest cost of cultivation (Rs. 56325) observed in $\left(\mathrm{P}_{3}\right)$ transplanted rice after reduced tillage (Fig. 3). The highest net return 
(Rs.37293) was observed in the treatment $\left(\mathrm{P}_{1}\right)$ conventional puddled transplanted rice followed by $\left(\mathrm{P}_{2}\right)$ transplanted rice on wide raised beds. The lowest net return (Rs.27883) was observed in $\left(\mathrm{P}_{3}\right)$ transplanted rice after reduced tillage. Similar results were also reported by Parihar et al., (2014), Puste et al., (2015) and Dabi et al., (2015).

Higher crop productivity with lesser cost of cultivation could result in better economic parameters like net returns and $\mathrm{B}$ : $\mathrm{C}$ ratio. In the current study, application of $100 \% \mathrm{RDF}+$ $5 \mathrm{t} / \mathrm{ha} \mathrm{FYM}+25 \mathrm{~kg}$ Zinc ha ${ }^{-1}+\mathrm{BF}\left(\mathrm{F}_{10}\right)$ recorded the highest net return $\mathrm{B}$ : $\mathrm{C}$ ratio. The higher yield realized under the above treatment would be the reason for more economic return as against the cost of cultivation with higher net gain and benefit: cost ratio. The result was conformity with the findings of Rajkumar (2003), who also realized higher economic return due to integrated nutrient management practices.

It is concluded from the foregoing discussion it is amply clear that conservation agriculture practices with integrated nutrient management play a key role to improving soil quality in the sub -tropical climatic conditions of India, and for minimizing the depletion of $\mathrm{OC}$ under continuous cropping, particularly in energy intensive double cropping regions. Conservation agriculture techniques with nutrient management practices help maintaining production sustainability without any detriment to the environment. Agro-ecoregion specific practical technologies need to be developed in the light of availability of various resources for making the best use of valuable data generated under tillage and nutrient management practices. The data acquired from the rice experiment revealed that tillage and nutrient management practices had significant effects, of varying magnitude, on growth and yield attributes and yield. Successful conservation agriculture mechanism integrated and soil fertility management would depend on a concerted effort by a multitude of factors (public and private). Working in a participatory mode is the need so as to enhance the production and economic viability of millions of smallholder farms currently struggling with declining soil fertility and poor management of plant nutrients.

\section{Acknowledgements}

We are grateful to the authorities of the Sardar Vallabbhai Patel University of Agriculture \& Technology, Meerut, U.P., India for all support in execution of this experiment. We also acknowledge the technical support from. Moreover, we would like to express our great respect for the editors and anonymous reviewers to improve the manuscript quality.

\section{References}

Ali M, Ali L, Waqar MQ, Ali MA. 2012. Bed planting: a new crop establishment method for wheat (Triticum aestivum 1.) In Cotton-wheat cropping system of southern Punjab. Int. J Agri App Sci. 4(1):8-14.

Anuradha, S., and Bharti, A. 2010. Effect of different crop establishment methods on growth, yield and economics of rice. Environ Ecol, 28 (1B):519- 522.

Beecher, H.G., Thompson, J.A., Dunn, B.W. and Mathews, S.K. 2005. Successful permanent raised beds in the irrigated farming systems of the Murrumbidges and Murray valleys of New South Wales, Australia

Bhuyan, M.H.M., Mst. R. Ferdousi, and Iqbal, M.T. 2012. Yield and Growth Response to Transplanted Aman Rice under Raised Bed over Conventional Cultivation Method. ISRN Agron, 6: 18. 
Dhaka AK, Bangarwa AS, Pannu RK, Garg R, Ramprakash. 2007. Effect of irrigation levels on consumptive water use, soil moisture extraction pattern and water use efficiency of different wheat genotypes. Indian J Agric. Res. 4(3): 220-223.

Dixit, K.G., and Gupta, B.R. 2000. Effect of farm yard manure, chemical and biofertilizers on yield and quality of rice (Oryza sativa) and soil properties. J. Indian Soc. Soil Sci., 48(4): 773-780

FAO. 2009. Food and agriculture Organization, Rome, Italy.

Ingle AV, Shelke DK, Aghav VD, Karad ML. 2007. Effect of irrigation schedules and nutrient management on WUE and nutrient uptake of wheat on vertisol. $J$ Soils Crops. 17(1):188-190.

Kumar, M., Yaduvanshi, N. P. S., and Singh, Y. V. 2012. Effect of integrated nutrient management on rice yield, nutrient uptake and soil fertility status in reclaimed sodic soil. J. Indian Soc. Soil Sci., 60 (2): 132-137

Kumar, N., K.K. Chandra and R. Singh, R. 2010. IPNS on growth, yield and economics of rice. Indian J. Fertil., 6 (2): $25-28$.

Kumar, V., Kumar, P., Singh, R., Kumar, D. and Singh, K. 2013. Effect of raised bed planting system on nutrient uptake and yield in rice-wheat cropping sequence. Annals Biol 29(1): 53-55.

Kumhar, B.L., Chavan, V.G., Rajemahadik, V.A., Kanade, V.M., Dhopavkar, R.V., Ameta, H.K. and Tilekar, R.N. 2016. Effect of different rice establishment method on growth, yield of different varieties during kharif season. Int $J$ Plant, Ani Environ Sci 6 (2):127-131.

Mohanty, M., Nanda, S.S., and Barik, A.K. 2013. Effect of integrated nutrient management on growth, yield, nutrient uptake and economics of wet season rice (Oryza sativa) in Odisha. Indian $J$
Agric Sci 83(6):599-604

Naresh, R. K., Gupta, R. K., Kumar, A., Singh, B., Prakash, S., Kumar, S. and Rathi, R. C. 2011. Direct-seeding and reduced-tillage options in the rice-wheat system of the Western Indo-Gangetic Plains. Int J Agri Sci, 7(1): 197-208.

Naresh RK, Rathore RS, Dhaliwal SS, Yadav RB, Kumar Dipender, Singh SP, et al., 2015. Crop Establishment Methods: Foliar and Basal Nourishment of rice (Oryza sativa) Cultivation Affecting Growth Parameters, Water Saving, Productivity and Soil Physical Properties. Paddy Water Environ. 3:373-386.

Page AL, Miller RH, Keeney DR. (eds.) Methods of soil analysis. Part 2. Chemical and microbiological properties, 1982.

Piper CS. Soil and Plant Analysis. Hans Publishers, Bombay, 1966.

Rajkumar, C. 2003. Study on the effect of different sources of nitrogen on growth and yield of rice. M.Sc. (Ag.) Thesis. AC\&RI, TNAU, Killikulam

Rana, K.S., Choudhary, A.K., Sepat, S., Bana, R.S. and Dass, A. 2014. Methodological and Analytical Agronomy. Post Graduate School, Indian Agricultural Research Institute, New Delhi, India. pp. 276

Reddy MM, Reddy MD, Reddy BB. 2004. Effect of $\mathrm{N}_{2}$ management through organic and inorganic sources on yield of rice. J Res. Angrau. 31(3):7-12.

Sengar SS, wade LJ, Baghel SS, Singh RK. 2000. Effect of Nutrient management on Rice in Rain-fed lowland of south east M.P. Indian J Agron. 45(2):315-322.

Shankar, L., and Laware. 2011. Effect of organic fertilizer on growth and yield components in rice (Oryza sativa L.) $J$ Agri Sci; 3 (3): 217-224.

Shrirame MD, Rajgire HJ, and Rajgire AH. 2000. Effect of spacing and seedling 
number per hill on growth attributes and yield of rice hybrid under low land condition. J Soil Crop. 10 (1):109-113.

Singh, B. and Singh, R.V. 2008. Effect of nutrient management on productivity and economics of transplanted rice crop. Int. J. Agric. Sci., 4 (2): 408- 410

Sridevi, V. 2011. Studies on crop establishment techniques on weed and nutrient management in low land rice. Ph.D. Thesis. TNAU, Coimbatore.

Thakur AK, Rath S, Roy chowdhury S, and Uphoff N. 2010. Comparative performance of rice with system of rice intensification (SRI) and conventional management using different plant spacings. J Agron Crop Sci 196:146159

Tripathi, M.K., Majumdar, B., Bhandari, H.R., Chaudhary, B., Saha, A.R. and Mahapatra, B.S. 2013. Integrated nutrient management in sunn hemp-rice cropping sequence in Eastern Uttar Pradesh, India. Indian J Agri Res, 47(3):22-25.

Uphoff N. 2003. Higher yields with fewer external inputs? The system of rice intensification and potential contributions to agricultural sustainability. Int J Agric Sustain. 1:3850

\section{How to cite this article:}

Vivek Kumar, R.K. Naresh, V.K. Tomar, Rakesh Kumar, Vivek, Ravindra Kumar, R.B. Yadav, N.C. Mahajan, Adesh Singh, S.P. Singh, Subhash Chandra and Omkar Singh Yadav. 2019. Growth, Yield and Water Productivity of Scented Rice (Oryza sativa L.) as Influenced by Planting Techniques and Integrated Nutrient Management Practice. Int.J.Curr.Microbiol.App.Sci. 8(06): 1369-1380. doi: https://doi.org/10.20546/ijcmas.2019.806.166 